\title{
Relationship between Giving Health Education to Mothers' Knowledge and Attitudes about Completeness of Immunization in Posyandu Bulo Village Walenrang District In 2018
}

\author{
Lindriani ${ }^{1}$, Nilawati Uly ${ }^{1}$ \\ 1) Mega BuanaPalopo College of Health Sciences, Palopo Indonesia \\ lindri82@yahoo.co.id \\ DOI: http://doi.org/10.29080/jhsp.v3i3S.279
}

\begin{tabular}{|c|c|}
\hline Keywords & Abstract \\
\hline $\begin{array}{l}\text { Attitude; } \\
\text { Completeness of } \\
\text { Immunization; } \\
\text { Health } \\
\text { Education; } \\
\text { Knowledge }\end{array}$ & $\begin{array}{l}\text { One of the factors decline of immunization coverage is community understanding which is } \\
\text { still limited. Even confused about immunization due to a lack of knowledge and attitudes of } \\
\text { parents towards immunization. The purpose of this research is to know the relationship } \\
\text { between giving health education to mother's knowledge and attitudes about completeness } \\
\text { of immunization in posyandu bulo village walenrang districtin 2018. The research design } \\
\text { was used quasy-experiment with one group pre and post test design approach. The } \\
\text { population in this research was all the mothers who came to bring her son to Posyandu for } \\
\text { immunization. The sampling technique used total sampling with the total samples were } \\
42 \text { respondents. The data that has been collected then processed and analyzed by using } \\
\text { computer and statistic program (SPSS) with T test-dependent. The results of this research } \\
\text { showed the differences with the increasing of mothers' knowledge after pre-test (p- } \\
\text { value=0,01) and there were differences with the increasing of mothers' knowledge after } \\
\text { post-test (p-value=0,01). The conclusion in this research was there were Relationship } \\
\text { Between Giving Health Education to Mother's Knowledge and Attitudes About } \\
\text { Completeness of Immunization in Posyandu Bulo Village Walenrang District in 2018. It is } \\
\text { expected that the next researcher will perform direct observation on the completeness of } \\
\text { immunizations. }\end{array}$ \\
\hline
\end{tabular}

\section{Introduction}

In Indonesia, part of the health development reference refers to the concept of "Healthy Paradigm", namely health development that gives top priority to efforts to improve health (Promotive) and prevention of disease (Preventive) compared to efforts to cure (curative) and recovery (rehabilitation) as a whole and integrated[1].

What Efforts so that people behave or adopt healthy behaviors by persuasion, persuasion, appeal, an invitation to provide information, provide awareness, etc. through activities called Health Education. Health Education is a form of intervention or effort aimed at behavior, so that the behavior is conducive to health. In other words, Health Education strives for the behavior of individuals, groups, or communities to have a positive influence on health care and improvement[2].

According to the Health Law Number 23 of 1992, the "Healthy Paradigm" is carried out through several activities, including prevention of disease. One effort to prevent infectious diseases is an effort to immunize or immunized[1].

Immunization is a way to actively raise/ enhance one's immunity against illness, so that if one day is exposed to the disease it will not be sick or only experience mild illness [3]. Even though at present, the service facilities for vaccination are available in the community, but not all babies have been brought to get complete immunization[4].

One of the factors decreasing immunization coverage is the unsufficient understanding of the community even to immunization due to the lack of knowledge and attitudes of parents towards immunization in infants. To determine the success of an immunization program, it is highly dependent on the tools to ensure vaccine effectiveness, and the readiness of health workers. One effort that can be done to increase the coverage of immunization for children under five is to provide health education to families. Health education is a dynamic process of behavior change with the aim of changing or influencing human 
behavior which includes components of knowledge, attitudes, or practices related to goals healthy living both individually, in groups and society. Components of a health program that is expected to increase public awareness in achieving government programs to tackle infant under five mortality[5].

Based on the research that has been done in the working area of Kartasura Public Health Center, Sukoharjo Regency with the title: Relationship between mother's knowledge and attitudes and the completeness of basic immunizations with results, there is a relationship between mother's knowledge and attitudes with the completeness of basic immunizations[6].

Based on the initial survey conducted in the District of Bulo Kecamatam Walenrang Subdistrict, BCG immunization coverage was 114 infants, POLIO4 as many as 111 infants, Complete Basic Immunization of 108 infants, DPT1 + HB1 as many as 63 infants, DPT3 + HB3 as many as 58 infants, and MULTIPLE 108 while the number of mothers who came to bring their children immunized as many as 42 people[7].

Therefore, the purpose of this study was to determine the relationship between the provision of health education with knowledge and attitudes of mothers about the completeness of immunization in Posyandu, Bulo Sub-District, Walenrang District, 2018.

\section{Methods}

The type of research used is a quasy-experiment Emethod is with control group. This research was carried out at the Walenrang Health Center which was held in February - March 2018.

The sample in this study was samples. The sampling technique used in this study was saturated/total sampling[8].

Primary data is obtained by distributing questionnaires to respondents. Before the health education was carried out, the respondents were given a questionnaire then after the respondent filled out the questionnaire then health education was conducted after the respondent was given a questionnaireto compare the mother's knowledge and attitudes before being given health education and after being given health education.

Data analysis was performed by quantitative analysis, which consisted of an univariate analysis (presented in frequency distribution) and bivariate analysis using the T-Dependent test presented in the SPSS version 20.0 program with an error rate $(\alpha=0.05)$.

\section{Results}

Table 1. Frequency Distribution Of Respondents' Knowledge and Attitudes Before and After The Provision Of health Education about The Completeness Of Immunizations in the Posyandu Working Area, Bulo Village Walenrang District 2018

\begin{tabular}{ccccc}
\hline \multirow{2}{*}{ Knowledge Level } & \multicolumn{2}{c}{ Before } & \multicolumn{2}{c}{ After } \\
\cline { 2 - 5 } Good & $\mathbf{f}$ & $\mathbf{\%}$ & $\mathbf{f}$ & $\%$ \\
Low & 13 & 31,0 & 33 & 78,6 \\
Total & 29 & 69,0 & 9 & 21,4 \\
& 42 & 100 & 42 & 100 \\
\hline Attitude & \multicolumn{2}{c}{ Before } & \multicolumn{2}{c}{ After } \\
\cline { 2 - 5 } Good & f & $\%$ & f & $\%$ \\
Not Good & 16 & 38,1 & 30 & 71,4 \\
Total & 26 & 61,9 & 12 & 28,6 \\
\hline
\end{tabular}

Source: Primary Data, 2018

Table 2. Relationship Distribution of Providing Health Education with Mother's Knowledge and Attitudes of Mothers About The Completeness of Immunization in the Posyandu Working Area in Bulo VillageWalenrang District in 2018

\begin{tabular}{cccccc}
\hline Knowledge & Mean & $\begin{array}{c}\text { Standard } \\
\text { Deviation }\end{array}$ & $\begin{array}{c}\text { Standard Error } \\
\text { Mean }\end{array}$ & n & p-value \\
\hline Before & 28,7143 & 2,30890 & 0,35627 & \multirow{2}{*}{0} & 0,001 \\
\hline After & 30,5000 & 1,90314 & 0,29366 & & p-value \\
\hline Attitude & Mean & $\begin{array}{c}\text { Standard } \\
\text { Deviation }\end{array}$ & $\begin{array}{c}\text { Standard } \\
\text { Error Mean }\end{array}$ & $\mathbf{N}$ & 0,001 \\
\hline Before & 49,3810 & 0,49151 & 0,07584 & 42 & \\
\hline
\end{tabular}




\begin{tabular}{crrr}
\hline After & 44,0000 & 9,60183 & 1,48159 \\
\hline
\end{tabular}

Source: T-Dependent Test, 2018

Table 1 shows that of the 42 respondents before being given Health Education a good level of knowledge was 13 respondents (31.0\%) and the low was 29 respondents (69.0\%). Whereas after being given health of education the level of knowledge was 33 people (78.6\%) and the low number was of 9 (21.4\%).

Table 2 shows that from 42 respondents before being given Health Education a good attitude amounted to 16 people (38.1\%) and the less good ones were 26 people $(61.9 \%)$. Whereas after being given health education showed a good attitude amounting to 30 people $(71.4 \%)$ and the less good numbered 12 (28.6\%).

Table 3 shows that the average knowledge of mothers' before being given Health Education is 28.7143 and Standard deviation $=2.30890$, with the average Standard Error $=0.35627$. While the average Knowledge of Mother after being given Health Education is 30.5000 and Standard deviation $=1.90314$ with the average Standard Error $=0.29366$. The value of $n=42$ and $p$-value $=0.001$. Because $p=0.001<\alpha=0.05$ then $\mathrm{HO}$ is rejected. This means that there is a relationship between the provision of Health Education and Mother's Knowledge about the completeness of Immunization at the Posyandu in Bulo Sub-District, Walenrang Sub-District in 2018. The provision of Health Education can increase Knowledge about the completeness of the baby's Immunization.

Table 4 shows that the average attitude of mothers before being given Health Education is 49.3810 and Standard Deviation $=0.49151$, with the average Standard Error $=0.07584$. While the average attitude of the mother after being given Health Education is 44,0000 and Standard Deviation $=9,60183$ with an average Standard Error $=1,48159$. The value of $n=42$ and $p$-value $=0.001$. Because $p=0.001<\alpha=0.05$ then $\mathrm{HO}$ is rejected. This means that there is a relationship between the provision of Health Education and Mother's Attitude about Immunization in the Posyandu in Bulo Sub-District, Walenrang Sub-District in 2018. Providing Health Education can improve the attitude of the mother about the completeness of her infant immunization.

\section{Discussion \\ Relationship between Providing Health Education with Mother's Knowledge about Immunization Completeness}

Based on the results of the study, it was found that there was a difference in the increase in knowledge of mothers about the completeness of immunization after a post-test was carried out where health education had previously been provided. Where it shows an increase in knowledge before and after being given health education that is from $31.0 \%$ with good knowledge to be as much as $78.6 \%$. This is shown in the hypothesis test with a t-test where $\mathrm{HO}$ is rejected because the significance value $(\mathrm{p}$-value) = $0.001<0.05$ and $\mathrm{H} 1$ is accepted in the research hypothesis. Then, it can be concluded that there is a relationship between the provision of health education and an increase in the knowledge of mothers about immunization.

Strengthening the effect of health education in knowledge is influenced by the characteristics of the mother, such as the age of the mother who is on average still young, so it is very easy to absorb the health education material provided.

The research was conducted at the black puskel in the working area of the Walenrang health center, which said that there was an influence of health education on the knowledge of mothers about basic immunization in infants. The results showed an increase in knowledge before and after being given health education, namely from $41.9 \%$ with good knowledge to be as much as $90.5 \%$ of good knowledge with $p$ value $=0,000[5]$.

The results of this study were supported by research conducted in Mancon Village, Wilangan Subdistrict, Nganjuk District, which said that there was an effect of health education on the knowledge of mothers regarding complete basic immunization. Based on statistical tests with T-test obtained value $t=$ 5.387 with ( $p$-value) $=0,000<0.05[1]$.

One strategy to change behavior according to WHO is to provide information to increase knowledge, so as to increase awareness to behave in accordance with knowledge they have. One effort to provide information is to provide health education[1].

\section{Relationship between Providing Health Education and Mother's Attitude About Immunization Completeness}

Based on the results of the study, it was found that there were differences in the increase in the attitude of mothers regarding the completeness of immunization after a post-test was carried out where health education had previously been provided. Where it shows an increase in attitude before and after being given health education which is from $38.1 \%$ with a good attitude to be as much as $71.4 \%$. This is 
shown in the hypothesis test with t-test where $\mathrm{HO}$ is rejected because the significance value (p-value) = $0.001<0.05$ and $\mathrm{H} 1$ is accepted in the research hypothesis. Then, it can be concluded that there is a relationship between the provision of health education with an increase in the attitude of mothers about the completeness of immunization.

In this study, there are limitations for researchers to control other factors, such as other people who can influence changes in the attitude of mothers about the completeness of immunization. So, it cannot be ascertained that the whole change is only influenced by health education.

The results of this study are in line with the research conducted in the balal puskel in the working area of North Luwu District Wara Health Center in 2015 which said that there was an effect of health education on the attitude of mothers regarding basic immunization in infants. $5 \%$ with good knowledge being as many as $87.8 \%$ good attitude with $\mathrm{p}$-value $=0,000[5]$.

The results of this study are also in line with research conducted in Mancon Village, Wilangan Subdistrict, Nganjuk District, which said that there was an influence of health education on the attitude of mothers regarding complete basic immunization. Based on the statistical test with the T-test obtained the value $\mathrm{t}=11.495$ with $(\mathrm{p}$-value $)=0,000<0.05[1]$

Conceptually, health education is an effort to influence or to invite other people, individuals, groups, or communities to carry out healthy behaviors. Practically, health education is all activities to provide and to improve people's knowledge, attitudes, and practices in maintaining and improve their own health[9].

After someone through the stage of stimulus or stimulation, the next process is to have or behave towards the stimulus or object. The manifestation of attitude cannot be directly seen, because it is a closed behavior. In other words, the attitude is a person's closed response to a particular stimulus or object, which has involved the opinion factor, and the emotions in question[10].

\section{Conclusion and Suggestion}

Mother's knowledge about the completeness of immunization showed an increase in knowledge before and after being given health education, namely from 13 0rang (31.0\%) with good knowledge to 33 people $(78.6 \%)$. With a significance value (p-value) $=0.001<0.05$, so, it can be concluded that there is a relationship between the provision of health education and the knowledge of mothers about the completeness of immunization.

Meanwhile, the attitude of mothers about the completeness of immunizations showed an increase in attitude before and after being given health education, namely from 16 orang (38.1\%) with a good attitude to as many as 30 people $(71.4 \%)$. With a significance value ( $p$-value) $=0.001<0.05$. So it can be concluded that there is a relationship between the provision of health education and the attitude of the mother about the completeness of immunization.

For nurses, it is expected that they can run a program to provide health education about the completeness of intensive immunization to the community, especially the mothers who have children to support increased awareness of the importance of giving immunization to their children.

\section{References}

1. Palupi. The Effect Of Immunization Counseling On Increasing The Knowledge And Attitudes Of Mother About Complete Basic Immunization In Infants Before The Age Of 1 Year. Essay. Surakarta: Eleven March 2011, University Medical Study Masters Program. (In Indonesia)

2. Notoatmodjo.Health Promotion and health Behavior.Jakarta :RinekaCipta; 2012: 105107Proverawati\&Andhini. Immunization and Vaccination.Yokyakarta: Medical Book; 2010:76(In Indonesia)

3. Proverawati \& Andhini. Immunization and Vaccination: Medical Book; 2010: 76(In Indonesia)

4. Anton.Description of Knowledga, Attitudes and Behavior of Mothers About Providing Complete Basic Immunization to Infants in The Working Area of The Selalong Health Center, Sekadau Sub-Distric, SekadauDistric. Pontianak Promontory Medical Journal, 2014;(5):1-8.(In Indonesia)

5. Sariaty.The Influence of Helath Education On The Knowledge And Attitudes of Mothers about Basic Immunization in Infants in The Bald Puskel in The Puskesmas Working Area North of Luwu District. Essay.S1 Nursing STIKES Kurnia Jaya PersadaPalopo; 2015. (In Indonesia)

6. Umaroh. The Relationship Between Knowledge and Attitudes of Mothers With The Completeness of Basic Immunizations in The Working Area of The Kartasura Public Helath Center, Sukoharjo Regency. Muhammadiyah Public Health Journal, 2014; (1);2-3(In Indonesia)

7. The Profile of Pustu In Bulo. Immunization Coverage DPT, HB, Measles,BCG, and Polio Based On The Sex, District and Pustu. Pustu In Bulo ; 2017(In Indonesia)

8. Sugiyono. Qualitative Quantitative research Methods and R \& D. Bandung: ALFABETA; 2012: 43(In Indonesia) 
9. Adnani.Public Health Textbook. Yogyakarta: Medical Book; 2011: 65(In Indonesia)

10. Istiyatuzzahra. The Effectiveness of Health Promotion Media in Changing People's Knowledge And Attitudes About Gastritis in Battang RT 01 RW 04 PalopoTownship.Essay. S1 Public Health STIKES Mega Buana Palopo;2015 (In Indonesia) 